\title{
Obraz Bratislavy v pamätiach a publicistike Mila Urbana Karol Csiba
}

CSIBA, K.: Bratislava in the Memoirs and Journalism of Milo Urban SLOVENSKÁ LITERATÚRA, vol. 68, 2021, no. 3, pp. 246-254

DOI: https://doi.org/10.31577/slovlit.2021.68.3.4

ORCID ID: 0000-0001-6738-107X

Key words: Bratislava, city, memoirs, social space, cultural journalism

The article looks at the ways Bratislava is portrayed in Milo Urban's (1904-1982) memoirs and journalistic texts. It starts with the reflection of an essay published in the mid-1930s in Elán magazine and continues with an analysis of the topographic outline of the city presented in the second and third part of Urban's memoirs. The latter texts provide a look at the city from the point of view of a stranger, newcomer. The descriptions give an insight into the emotional state of the narrator and his view of Bratislava, characterised by his exclusion from the social space of the city. The texts also contain musings on urban imagination. Common attributes of all analysed texts lie in the confrontation of modernisation with Slovak tradition. The article also outlines the possibilities of further research into Urban's work through the analysis of urban topoi: the formerly unfamiliar Bratislava gradually becomes a known and natural space - although this process is a problematic and not finite one.

Klúčové slová: Bratislava, mesto, pamäti, sociálny priestor, kultúrna publicistika

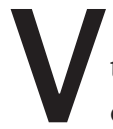
roku 1931 publikoval Vladimír Clementis v časopise $D A V$ článok Hmlistý komunizmus v Hmlách na úsvite (Clementis 131: 7). Uvažuje v ňom o aktuálnosti prozaickej tvorby Mila Urbana a tiež o prozaikovej snahe a schopnosti ovplyvňovat' súčasnost'. Jednotlivé Urbanove diela nespája V. Clementis s kontextom slovenskej literárnej tradície. $\mathrm{V}$ tejto súvislosti pripomína konštatovanie Karla Čapka z rozhovoru uverejnenom v časopise Elán, podl'a ktorého by sa mala slovenská literatúra perspektívne zamerat' na isté „oslavné“ 
tematizovanie slovenského života. ${ }^{1} \mathrm{~S}$ touto predstavou sa V. Clementis nestotožňuje. Svoj pohl'ad aplikuje na Urbanov román Hmly na úsvite (1930), so zameraním na tematizáciu sociálnych problémov. Nevšíma si teda literárnu úroveň diela, číta ho skôr ako sociologický a politický portrét súvekého Slovenska. Oceňuje najmä prozaikovu ochotu prekračovat' status neutrálneho spisovatel'a a úsilie ponúknut čitatel'om úvahu o dobovej spoločnosti. Problém nachádza v komplexnosti jeho analýz, čo sa podl'a neho prejavuje aj pri zobrazovaní mesta. O Urbanovom tematickom koncepte píše:

„Ked' je na dedine, valia sa z neho slová, ako jarné vody z Pil'ska. Na mestskom asfalte pohybuje sa opatrne, akoby musel rozmýšlat' nad každým slovom, nad každým krokom. A jeho výprava do mesta končí útekom na dedinu, kde za pomoci vysneného kaplána Ilečku, obráteného Sedmíka a hlavatého Hlavaja chce stvorit' nového človeka, nezataženú generáciu. Ale je toto skutočne možné východisko?" (Clementis 131: 7).

Urbanovo príbehové riešenie hodnotí V. Clementis ako výsledok prozaikovho nepochopenia a zahmlievania zákonitostí robotníckeho sveta, ktorý on sám považuje za jednoznačného „nositela budúcnosti“. Odmieta tiež Urbanov obraz mesta. Neschopnost' subjektu integrovat' sa v jeho priestore vníma ako nereflektovanie jeho modernosti zo strany prozaika, čo potvrdzuje aj návrat románového protagonistu na vidiek.

V tret'om čísle časopisu Elán z roku 1935 publikoval M. Urban úvahový článok Autor na rázcestí: dedina či mesto? (Urban 1935: 1-2). V kontexte jeho diela má táto úvaha programový ráz. Približuje autorovu predstavu o zobrazovaní mesta v aktuálne vznikajúcej slovenskej literatúre. Ako impulz k jej napísaniu uvádza Urban tézu takzvaných ,pozorovatel'ov“ slovenského literárneho života (kritikov, teoretikov, publicistov), ktorí poukazovali na dobový nezáujem slovenských spisovatelov o literárne zobrazovanie mestského prostredia. Sám sa sústreduje na žáner prózy, najmä na romány, pričom sa opiera aj o vlastnú čitatel'skú skúsenost'. Ani on nenachádza v dielach mestské námety, čo chápe ako zámer samotných domácich tvorcov. Tento stav sa podla jeho slov dotýka predprevratového obdobia a kontinuálne aj situácie po prevrate v roku 1918, čo pri zmene spoločenských podmienok definuje ako určitý paradox. Absenciu mestských tém v literatúre identifikuje i v hodnoteniach situácie samotnými slovenskými spisovatel'mi. V niektorých prípadoch vidí pokusy zmenit' danú nepriaznivú situáciu a úsilie literárne zachytit' prostredie mesta. Svoje tvrdenia však nekonkretizuje. $\mathrm{Z}$ nedostatočného spracovania urbánnej témy však neobviňuje iba samotných tvorcov. Príčiny neschopnosti slovenskej literatúry umelecky sa vyrovnat' so špecifikami mesta považuje za mimoriadne zložité a komplexné. Spája ich s dovtedajším domácim kultúrnym vývinom.

1 V rozhovore so Štefanom Letzom sa K. Čapek vyjadril nasledovne: „Myslím, že slovenská literatúra doposial'ešte nedala to, čo mala dat'.Život v plnej jeho harmónii. Pred prevratom bola viac-menej protestom proti panujúcim pomerom a ako taká nebola bez istej jednostrannosti. Slovenská literatúra potrebuje, aby prestala byt' protestom a stala sa oslavou slovenského života“ (Letz 1931: 3). 

mestskú" (Urban 1935: 1). Slovenských spisovatel'ov priraduje k vidiečanom a národne uvedomelým občanom, ktorí aj napriek osobnej skúsenosti nenachádzajú $\mathrm{v}$ tomto priestore duchovnú oporu. Mestský život zostáva v ich predstavách neznámy a cudzí. Neúspech viacerých tvorcov v aktívnom zapojení sa do jeho diania sa aj z tohto dôvodu mení na odpor voči novému priestoru. Riešením je fyzický (osobný) a motivický (tvorivý) návrat k vidieku.

V komplikovanom vztahu spisovatel'ov k mestu odkrýva M. Urban príčinu spôsobujúcu nárast a hromadenie rôznych variácií literatúry situovanej do dedinského a malomestského prostredia. Základný nedostatok takýchto diel vidí v tematickej jednostrannosti a myšlienkovej sterilite. Práve tieto atribúty próz prepája s umeleckou a intelektuálnou úrovňou predprevratovej spoločnosti. Zároveň dodáva, že v prostredí kultivovanejších čitatel'ov aktuálne rezonuje požiadavka na sofistikované stvárnenie portrétu mesta. Kriticky sa vyjadruje aj k odkazu starších (predprevratových) literárnych generácií, ktoré podla jeho slov nezanechali nasledovníkom relevantné umelecké východiská, čo má potvrdzovat' $\mathrm{i}$ absencia témy mesta. Riešenie situácie vidí nielen $v$ premenách samotnej literatúry, ale aj vo vývine slovenskej spoločnosti.

Všíma si najmä aktuálny nárast počtu slovenských obyvatelov miest. Poukazuje na zintenzívnenie kultúrneho života Slovákov, od ktorého odvodzuje čitatel'ské očakávania smerujúce k jednotlivým autorom. Práve spisovatelia by sa podla jeho názoru mali sústredenejšie venovat' reflexii novej formy života slovenskej spoločnosti. V ambíciách spisovatel'ov identifikuje ochotu uspokojit zvýšený čitatel'ský záujem o tému mesta, no poukazuje tiež na isté komplikácie. Literárne spracovanie témy mesta prirovnáva $\mathrm{k}$ „priekopníckej práci“, ktorá okrem umeleckého nadania vyžaduje aj niečo iné: „Čitatelia a kritika chcú hotový čin. Ked' ho nenájdu, vysmejú sa spisovatelovi. A ten za to ani nemôže, lebo hlavná pričina je mimo neho" (Urban 1935:2). Píše takisto o dalších prícinách určitého vyhýbania sa téme mestského prostredia v slovenskej literatúre. Za klúčovú považuje takzvanú dedinskú determinovanost', ktorá väčšine slovenských spisovatel'ov komplikuje identifikáciu s inak štruktúrovaným mestským prostredím, čo sa prejavuje tiež v odlišnom využití výrazových prostriedkov.

Ďalší problém nachádza M. Urban v spôsobe uvažovania tvorcov. Úsilie o literárne definovanie charakteru mestskej spoločnosti totiž spája s dôkladným spoznávaním ešte neznámeho prostredia. Proces rekognoskácie priestoru by však nemal byt' jednostranný:

„Kaviareň, pijatika pod viechou, zmyselné okúzlenie v bare a nejaké lúbostné dobrodružstvo, to je nie mestský život, ako si mysleli niektorí naši spisovatelia. To sú len malé epizódky, zážitky, i to obyčajne len vidiečanov, ktorí 
si prídu do mesta vyhodit' z kopýtka. Prirodzene, mesto a jeho život v takomto 249 ponímaní vyrástlo im potom v akúsi fantastickú, nemožnú vidinu, a mestské postavy v akési nepravdepodobné papierové figúry, za ktorými staby ste videli nitky a spisovatel'a v úlohe riaditel'a bábkového divadla, hovoriaceho zmeneným hlasom strašidelný text" (Urban 1935: 2).

Umelecky relevantné romány určované témou mesta sú do značnej miery závislé od ochoty spisovatel'ov zaoberat' sa nielen nočným, ale rovnako aj denným životom, ktorý charakterizuje špecifická filozofia. Nevyhnutná je podl'a M. Urbana aj premena literárneho jazyka. Píše o nevyhovujúcom, lexikálne a štylisticky tvrdom jazyku vidieckych románov. Literárne reflektovanie mesta považuje za umeleckú výzvu pre každého moderného spisovatela.

Porovnanie dvoch textov uverejnených v časopisoch DAV a Elán poodhaluje zaujímavý pohl'ad na spracovanie témy mesta v slovenskej medzivojnovej literatúre. Clementisova reflexia románu Hmly na úsvite do značnej miery potvrdzuje tradovaný obraz M. Urbana, ktorý sa v dvadsiatych rokoch etabloval ako vidiecky a do značnej miery aj regionálny autor. Urbanova koncepčná úvaha tento autorský obraz čiastočne porušuje. Text je príznačný pre obdobie, ked' sa mesto objavilo aj pred najmladšími generáciami slovenských tvorcov ako komplexný problém. M. Urban v druhej polovici tridsiatych rokov, v čase publikovania svojej úvahy, mesto literárne nesprítomňuje. Dôvodom je, že sa beletristicky odmlčal. K publikovaniu próz sa vrátil až románom V osídlach (1940). V románe Hmly na úsvite je mesto sprostredkované očami dedinčana, na čo upozornil v recenzii K. Čapek (Čapek 1935: 4-6; knižne Čapek 1986). Záujem M. Urbana o mestský priestor je však viditel'ný v pamätiach, ktoré napísal o niekol'ko desat'ročí neskôr. Sú žánrovo odlišným textovým materiálom, implicitne nadväzujúcim na východiská jeho koncepčnej úvahy z Elánu v roku 1935.

Poprevratové obdobie života na Slovensku zachytáva druhý zväzok Urbanových pamätí Kade-tade po Halinde (1992). Situáciu pred druhou svetovou vojnou a vojnové roky následne spracováva tretia čast' nazvaná $\mathrm{Na}$ brehu krvavej rieky (1994). Obe knihy značne parciálnym spôsobom reflektujú aj obraz Bratislavy. Spôsob zobrazenia mesta je prepojený s autorským hodnotením vlastnej existencie a jej kvalitatívno-existenčných premien. $V$ druhej spomienkovej knihe je vykreslená Urbanova prvá intenzívnejšia skúsenost' s Bratislavou, v spojitosti s letnými prázdninami v roku 1923, ked'bol žiakom Štátnej vyššej lesníckej školy v Banskej Štiavnici. Negatívny pohl'ad na mesto súvisel najmä so sklamaním zo slúbenej pracovnej výpomoci v redakcii denníka Slovák. Charakter práce a kvalita ubytovania nesplnili jeho očakávania. Pocity rozčarovania charakterizujú už prvotný kontakt s mestom:

„Slávobrána v Bratislave chýbala. Umelca nik nevital. Po hodinovom blúdení, a zas len č́rou náhodou, trafil som do Svoradova (starého, lebo o novom sa vari ešte nikomu ani nesnívalo), no môj prvý dojem bol, že som zašiel prid'aleko-až ta, do rímskych katakomb. Z dvora do izieb napríklad sa nešlo ako zvyčajne nahor, ale nadol. A trafit'doň... Nedajbože! Ažvtedy som zbadal, že som, doma', ked'som pred sebou zazrel obludnú, najošarpanejšiu bránu na celej Zámockej ulici. Kompletnýstredovek. 
250 A ktomu ešte krstenýslovenskou biedou a či nedbajstvom-neviem. Sem som mohol príst' ajv laptiach. K takej bráne sa ony priam žiadali. Ale kto vedel“" (Urban 1992: 86-87).

Odchod z mesta dopíňa rozhodnutie nevrátit' sa. Naopak, nástup M. Urbana do redakcie denníka Slovenský národ v roku 1925 sprevádza celkom iný dojem z Bratislavy. Zmenu postoja vystihuje nasledovný citát: „Pred dvoma rokmi, ked'som po onom pochybnom živote umelca v studenej chodbičke starého Svoradova takmer ozlomkrk opúśt́al Bratislavu, božil som sa vduchu, že ma tam l'ahko neuvidia. A hl'a. Neminuli ani dva roky, a ja som sa zas a skoro ozlomkrk vracal" (Urban 1992: 135-136). Pri reflexii tejto etapy Urbanovho života predstavuje Bratislava priestor, s ktorým sa spája okrem každodenných životných epizód aj problematika mužskej elegancie, modernosti a zmyslu pre módu. Jednotlivé spomienky Urban väčšinou fixuje na okruh vtedajších priatel'ov a kolegov:

„Jožko Nižnánsky mal už vtedy určité redaktorské skúsenosti. [...] Inak Jožko bolv Bratislave široko-d'aleko známy ako arbiter elegancie, človek so znamenitým vkusom, vždy ako zo škatul'ky vytiahnutý. Mohol som mu robit' hanbu? Mal vedl'a seba trpiet' ozembucha, ktorému len-len že netrčali lakte, kolená a ešte čosi z lacného konfekčného oblečenia od Neheru? A teraz! Už som nemusel šetrit'. Mal som mesačne tisícosemsto korún na dlaň. Nemusel som robit' hanbu novému časopisu, Bratislave a Slovákom uprostred záplavy Mad'arov a Nemcov, ktorísi potrpeli na obliekanie“ (Urban 1992: 137).

Do takýchto obrazov vkladá tiež momentky z intenzívne prežívaného kaviarenského života, predstavujúceho pokračovanie vtedajšej redakčnej práce. ${ }^{2}$ Nikdy však nebol agensom diania či zábavy. Častejšie odkazuje na vlastný pocit istej „nepriliehavosti“ k prostrediu bratislavskej bohémy, svojej nenáležitosti v ňom. ${ }^{3}$ Ani v spomienkach na opätovný príchod do Bratislavy, do ktorej sa vracia po pobyte na Orave a dokončení románu Živý bič (1927) v januári 1928, však nechýba opis kaviarne:

„A teda zas Bratislava. Ako a kde som sa etabloval... Vypadlo z pamäti. Ostala v nej iba nová kaviareň Astória, plná svetla a hudby. Otvorili ju ani nie pred rokom. Po starosvetských bratislavských kaviarňach pre vel'ké obloky a výhl'ad z poschodia chytro prichádzali do módy [...] Po návrate do Bratislavy hore na poschodi Astórie - pohŕdajúc nesympatickým majitelom - v nedostatku inej roboty vysedával som i ja. Pravdaže, nie sám. Hned'sa ma ujala spoločnost' podobných stroskotancov [...] Tvorili sme senzačnú spoločnost" (Urban 1992: 174-175).

2 „Robotu sme vtedy nemerali centimetrom. Nie, nehladeli sme na hodinky. Ba čo viac, v akejsi pracovnej extáze nekončili sme ju ani v redakcii. Po patričnom výdychu ledva sme sa dočkali súmraku. A len čo začali zapal'ovat' svetlá, už sme sa ponáhl'ali k dunajskému mostu - do kaviarne Baross (dnešný Krym) a tam... Neviem, čo to bolo. Ticho, ktoré tol'kým lahodí, bez ktorého si nemôžu predstavit' sústredenú prácu, nás akoby mýlilo“ (Urban 1992: 145).

3 „Mali už svoje vychodené cestičky a vel'ký dvor ctitel'ov, do ktorého sa začínajúci autorík iba náhodou dostal. Mne náhoda nežičila, a ani som ju nenaháňal. Stačili mi legendy o tom, ako sa kde zabávali, a zakaždým sa ma zmocňoval onen zázrivský pocit, že som ešte nedorástol do ozajstnej chlapskej zábavy“ (Urban 1992: 148). 
Na viacerých miestach memoárov deklaruje Urban individuálnu neschopnost'zapojit' sa do aktívneho formovania bratislavskej umeleckej spoločnosti. Rovnako tento Urbanov pobyt $v$ Bratislave končí odchodom, ktorý je výrazom nespokojnosti s vlastným životom. Iba chvíl'kovým útekom bol pre neho pobyt v kúpel'och. ${ }^{4}$

Atmosféru Bratislavy konfrontuje M. Urban v druhom zväzku pamätí s inými mestami. Poukazuje na význam Martina a Prahy, ktoré charakterizuje ako miesta úniku z bratislavského prostredia. Presnejšie o tom píše: „Praha mi bola bránou do sveta a Martin oknom do slovenského života. Obe mestá mi v hojnej miere poskytovali to, čo Bratislava vtedy ešte nemala a teda nemohla poskytnút" (Urban 1992: 228). Opisuje ich ako bázy literárnych inšpirácií, modifikujúce a prehlbujúce jeho „jednostranný bratislavský“ uhol pohl'adu na svet. Diskrepanciu vo vztahu k Bratislave odhalujú aj často opakované informácie o neúplnom splývaní so spoločnostou bohémov, čo však nevyhodnocuje ako fakt, ktorý by ho sociálne ,znevýhodňoval“. 5

Odlišný obraz Bratislavy je stvárnený v tret'om zväzku pamätí. Urban sa v ňom zameriava na obdobie druhej svetovej vojny, no všíma si aj čas pred jej vypuknutím. Zachytáva zlomové momenty vlastného života. $\mathrm{V}$ tomto kontexte je klúčová informácia o sobáši so Žofiou Paňákovou v auguste 1935 a tiež jeho uvolnenie z redakcie Slováka a následné poverenie vedením redakcie Gardistu v novembri 1940. Najmä svadba a založenie rodiny ovplyvňujú Urbanov obraz Bratislavy. Dominantné momentky z prostredia bratislavskej bohémskej spoločnosti a autorov subjektívny itinerár kaviarní striedajú obrazy determinované rodinným životom. Priestor mesta neraz nahrádza interiér bratislavského bytu:

„Hovorilo sa stále o dvojizbovom byte. Lež popravde: bola to len jedna väčšia izba (všetka čest', skrásnym výhl'adom na mesto, na Dunaj) a pri nej čosi ako kabinet, do ktorého sa nepopratal ani môj mládenecký nábytok. Lenže my sme netúžili po vel'kých priestoroch. Nájomné bolo nizke, akoby šité na nás, a bytík voñal vápnom, farbou, čistotou, až zadúšalo" (Urban 1994: 4).

Podobným spôsobom charakterizuje aj neskoršie stahahovanie rodiny z malého bytu na Kalvárii do väčšieho a modernejšieho priamo v centre mesta na Gajovej ulici:

„Vláčit'nákupy z mesta pešo do takého kopca, a k tomu eštev druhom stave, naozaj vyčerpávalo. I bytík sa žiadal väčší. Našli sme ho vo vel'kom dome na spomenutej ulici: dve pekné izby, hala, izbička pre pomocnicu a ústredné kúrenie. Bývali sme sice na tretom poschodí, ale bol tam výtah a spol'ahlivýdomovník, takže sme sa nemali na čo stáažovat"“ (Urban 1994: 61).

4 „Vedel som, že Ivan Stodola je vel'korysý človek, že si takto rok čo rok pozýva niekoho zo slovenských umelcov, aby mu poskytol trochu oddychu. Ale ved' ja som dokopy ešte nič nespravil, naopak, oddychujem si, až mi je z toho nanič. Lenže lámat' si nad tým hlavu. Načo? Bratislavy mal som už aj tak po krk. Vysedávanie v Astorke sa mi prejedlo, rozpálené, zapáchajúce ulice a dusné noci s mačacími mítingmi ma čoraz viac rozčul'ovali, nuž povedal som si: Volajú... Idem!“ (Urban 1992: 181).

5 „Hoci som nepatril k opravdivej bratislavskej bohéme, naskytla sa nejedna príležitost' nazriet' do jej tajov. Vo vtedajšej Bratislave totiž, kto nebol vysloveným mníchom, musel sa o ňu vol'ky-nevol'ky obtriet'. No a ja som bol všetkým možným, len mníchom nie“ (Urban 1992: 297). 

vratom do bratislavskej cudzoty, do starého zhryzoviska, a popudený ćmsi nemilým, už ani presne neviem čím, zrazu som sa rozhodol spravit'bodku za touto nepokojnou, ubijajúcou kapitolou svojho života" (Urban 1994: 95).

V d'alších kapitolách spomienok venuje Urban Bratislave už len minimálnu pozornost'. V týchto ,zvyšných“ obrazoch znova dominuje dezilúzia spomínajúceho. Do popredia sa dostávajú témy ako presun redakcie Gardistu do Žiliny, emigrácia zo Slovenska, pobyty v amerických zajateckých táboroch na území Rakúska a väzenie v Prahe a Bratislave. Dezilúzia sa v závere tretieho zväzku memoárov strieda s vynechávaním spomienok. Takýmto prázdnym miestom sa stáva aj samotný obraz Bratislavy. ${ }^{7}$

V topografickom náčrte mestského prostredia Bratislavy, ako ho podávajú druhá a tretia čast'Urbanových pamätí, dominujú toposy charakteristické pre perspektívu pristahovalca (príchod do mesta, komplikované adaptovanie sa na jeho fungovanie, obraz kaviarne ako miesta práce, hl'adanie ubytovania a podobne). Urbanov literárny obraz mesta, najmä v dielach vydaných po románe Hmly na úsvite, bol však iný. Aj preto sa ako relevantná téma d'alšieho výskumu ukazuje konfrontácia Urbanových pamätí, jeho tematicky príbuznej publicistiky a umeleckých próz.

V pamätiach splýva autorovo zobrazovanie mesta so spomienkami na to, čo bolo predtým a čo sa nenávratne zmenilo. Umelecká predstavivost tvorcu sa v nich mieša s overitel'nými stopami minulosti, mapovaný je však aj proces ich vymazávania. Interpretácia mesta má často podobu kolektívne preživaného priestoru (Huyssen 2005: 21-22), ktorého viaceré konfigurácie zodpovedajú kolektívnej pamäti (obraz redakcie, kaviarní a podobne). $V$ kontexte perspektívy pristahovalca je v pamätiach tematizovaný problém vnútornej rovnováhy jednotlivca. Každodenný nemenný kontakt s identickými predmetmi vytvára dojem stability a trvalosti (Halbwachs 2009: 185), čo je v obraze Urbanovej existencie v Bratislave spojené s navodzovaním pocitov pokoja a poriadku. Spomínajúci subjekt prechádza od chvil'kových pocitov straty orientácie v cudzom priestore k nachádzaniu záchytných bodov. Opis tohto procesu nevynecháva ani okolnosti zmeny materiálneho prostredia. Proces zvykania si je sprevádzaný obdobím neistoty, ktorej výsledkom je v mnohých ohladoch premena osobnosti (Halbwachs

6 Poukazuje na to aj takáto charakteristika: „V Bratislave sa dovtedy nežilo najhoršie. Boli problémy, to je pravda. I biedy, a horúcej, sa dost' našlo. Sem-tam si zademonštrovali robotníci, sem-tam vysokoškoláci robili hurhaj pri Štúrovej pamätnej tabuli, ale ked'policajti obuškami ,zjednali poriadok ‘ - ako sa vtedy ešte zhusta vravelo-v meste nad Dunajom zavládol pokoj. A len čo sa zvečerilo, bývalo i veselo“(Urban 1994: 34). 7 „Či som medzitým bol v Bratislave? Neviem povedat'. Mohol som íst'. Ved' zatykač na mňa zrušili. A ked' nič iné, mohol som sa aspoň o sebe dačo dozvediet'. Mňa však do Bratislavy nič netahalo. Ved' čo by som tam robil? Kým nebude po procese, kým neviem, na čom som, i tak si s ničím neporadím. Ešte by si dakto pomyslel, že som prišiel prosit' o milost" (Urban 1994: 224). 
2009: 185). V prípade Urbanových pamätí sa to okrajovo dotýka napríklad zme- 253 ny spôsobu obliekania (nejde už len o výmenu dedinských šiat za mestské, čo je jeden zo znakov urbanizácie na individuálnej úrovni, ale predovšetkým o aspekt elegancie a istej noblesy ako výraz vyššieho sociálneho statusu). Udomácnenie sa v mestskom priestore sa u Urbana deje súbežne s prijatím ideologicky exponovaných postov v redakciách periodík Slovák a neskôr Gardista. Pocit čiastočného či komplexného vylúčenia subjektu zo sociálneho priestoru mesta (Marcelli 2008: 53) je v takýchto momentoch zmenený na pocit integrácie v ňom. Moment pochybnosti o trvalom stave sa však z memoárového naratívu nevytráca, ale predstavuje jeho návratný motív. V tejto situácii sa stáva dôležitou téma kaviarní, prostredia, ktorého relevancia je zrejmá aj z recepcie Urbanových pamätí. Z určitého uhla pohl'adu sa ich existencia ukazuje ako trochu efemérne riešenie problému, ktoré sa dá akceptovat' pod podmienkou vnímania kaviarenského sveta ako útočiska pre individuality pocitujúce odcudzenost' od spoločnosti, v ktorej žili (Bradshaw 1988:12). Do Urbanovho mestského koloritu patrili aj návštevy nočných barov, kam sa bratislavská umelecká bohéma presúvala práve z kaviarní a viech, hoci tento obraz bol takisto selektívny. Ako v tejto súvislosti napísal historik Martin Vašš,

„kým sa meštiaci z viech poberali domov, protagonisti zlatej bohémy pokračovali svojou nočnou pútou v nočných baroch, prípadne v hostinci Zlatá fantázia. [...] Nočné bary oproti iným typom lokálov ponúkali aj eroticky zvodný tanec tanečníc, ktoré po skončení svojich čísel neraz slúžili ako prostitútky. V memoároch aktérov umeleckej bohémy sa však nezachovala ani jedna zmienka o tom, že by využili erotické služby tanečníc z nočných barov“ (Vašš 2018: 57).

Aj v prípade Urbanovho zobrazovania podobných zákutí mesta dochádza k literárnym posunom ich charakteru. Paradoxne, aj tieto miesta pozitívne ovplyvňujú proces jeho prispôsobovania sa novému životnému priestoru, hoci on sám si prisudzuje väčšinou iba rolu tichého pozorovatel'a udalostí. Definícia priestoru má v tomto prípade charakter určitej kulisy a obrazu (Hodrová 1997: 15), ktoré determinujú špecifické vztahy medzi protagonistami.

Urbanove memoáre a medzivojnová publicistika predstavujú jednu kapitolu príbehu formovania moderného mestského života na Slovensku, ktorý sa v dvadsiatych rokoch 20. storočia už odohrával predovšetkým v Bratislave (Habaj 2018: 11-27). Obe žánrové polohy ukazujú spôsoby, ako sa obrazy modernizácie dostávajú do stretu s obrazmi tradície. Na tematickej ploche Urbanových pamätí je to premenlivý, problematický a najmä neukončený proces zmeny Bratislavy ako cudzieho priestoru na priestor prirodzený. Na pozadí tohto priestorového osvojovania prebieha hodnotový konflikt medzi rurálnym a urbánnym, ktorý dlhodobo predstavoval jeden z tažiskových ideových problémov slovenskej kultúry. Pre Urbana predstavuje moderné mestské prostredie miesto životného naplnenia a dynamiky, no zároveň je priestorom odcudzenia. $V$ kontexte takýchto úvah má Urbanov obraz Bratislavy podobu subjektívneho a dobovo determinovaného svedectva o slovenskej spoločnosti tých čias. Reflektovaná ambivalentnost' tohto obrazu naznačuje jednu z možností d'alšieho výskumu Urbanovho diela. 
254 Štúdia je výstupom grantového projektu VEGA 2/0066/20 Modernizmus v slovenskej literatúre II. Zodpovedný riešitel': Mgr. Michal Habaj, PhD. Doba riešenia: 2020 - 2023.

\section{Pramene}

CLEMENTIS, Vladimír, 1931. Hmlistý komunizmus v Hmlách na úsvite. DAV, roč. 4, č. 3, s. 7. ČAPEK, Karel, 1935. O slovenské literatuře (Několik slovenských románů). Přitomnost, roč. 12, č. 1, s. 4-6.

ČAPEK, Karel, 1986. Spisy o umění a kultuře III. Praha: Československý spisovatel.

LETZ, Štefan, 1931. Štvrt' hodinky s Karlom Čapkom. Elán, roč. 1, č. 7, s. 2.

URBAN, Milo, 1935. Autor na rázcestí, dedina či mesto? Elán, roč. 6, č. 4, s. 1-2.

URBAN, Milo, 1992. Kade-tade po Halinde. Bratislava: Slovenský spisovatel'. ISBN 80-220-0412-X.

URBAN, Milo, 1994. Na brehu krvavej rieky. Bratislava: Slovenský spisovatel'. ISBN 80-220-0540-1.

\section{Literatúra}

BRANDSHAW, Steve, 1988. Kaviarenská spoločnost'alebo život bohémov od Swifta po Dylana. Bratislava: Tatran.

HABAJ, Michal, 2018. K obrazu mesta v slovenskej poézii dvadsiatych rokoch 20. storočia. In ŠRANK, Jaroslav, ed. Podoby mesta v slovenskej poézii 20. storočia. Bratislava: Univerzita Komenského, s. 11-27. ISBN 978-80-223-4622-1.

HALBWACHS, Maurice, 2009. Kolektivní pamět'. Praha: Sociologické nakladatelství SLON. ISBN 978-80-7419-016-2.

HODROVÁ, Daniela, 1997. Pamět a proměny míst. In HODROVÁ, Daniela a kolektiv. Poetika míst. Praha: $\mathrm{H} \& \mathrm{H}$, s. 5-24. ISBN 80-86022-04-8.

HUYSSEN, Andreas, 2005. Prítomnost'minulého. Urbánne palimpsesty a politika pamäti. Bratislava: Vydavatel'stvo Ivan Štefánik. ISBN 80-968189-8-8.

MARCELLI, Miroslav, 2008. Filozofiv meste. Bratislava: Kalligram. ISBN 978-80-8101-013-2. VAŠŠ, Martin, 2018. Zlatá bohéma. Umelecká bohéma v Bratislave. Bratislava: Marenčin PT. ISBN 978-80-8114-940-5.

Mgr. Karol Csiba, PhD.

Ústav slovenskej literatúry SAV

Dúbravská cesta 9

84104 Bratislava

Slovenská republika

E-mail: csiba0@gmail.com 